\title{
PROTECTION OF RIGHTS OF TAXPAYERS THAT ARE NOT DEFINED AS PHYSICAL PERSONS IN POLAND
}

\author{
PIOTR WOLTANOWSKI', RÓŻA KOSIŃSKA ${ }^{2}$, JOANNA CZAPSKA ${ }^{3}$
}

\begin{abstract}
Taxpayers, who are not physical persons, mostly use an institution of the Ombudsman or they file a constitutional complaint to Constitutional Tribunal in Poland. Their professional preparation and greater financial strength result in ousting of physical persons - as entities without the satisfactory support of legal advisors - from competition in access to the protection of their rights by the Ombudsman. The problems rather originate from the unsatisfactory level of financing of Polish Ombudsman. Thus, the Ombudsman would avoid commissioning external expert's report and legal opinions and instead would prefer to focus on applications, in which requesting entities provide such documents on their own. In case of the constitutional complaint, the basic difficulty is a lack of professionalism of (surely cheaper) legal counselors and lawyers who serve physical persons. Lately, some works have been initiated to establish a new institution to protect taxpayers' rights - Ombudsman of Taxpayers' Rights. This signalized change is expected to be rather quantitative than qualitative - a new organ is going to double functions of the classical ombudsman.
\end{abstract}

1 Board Member and General Secretary of Information and Organization Centre for the Research on the Public Finances and Tax Law in the Countries of Central and Eastern Europe, Department of Public Finances and Financial Law, Faculty of Law, University of Bialystok. He is the author of over 50 publications in the field of tax administration, human rights, health service finance and social security. Contact email: piotrwoltanowski@ gmail.com.

2 Member of the Audit Committee of Information and Organization Centre for the Research on the Public Finances and Tax Law in the Countries of Central and Eastern Europe, Secretary of Drohiczyn Scientific Society. An experienced practitioner of economics, a long-standing employee of the tax apparatus, an external and internal risk analyst, author of many publications in the field of tax administration. Contact email: rozmark@wp.pl.

3 Member of the Information and Organization Center for the Research on the Public Finances and Tax Law in the Countries of Central and Eastern Europe since 2017. Chief specialist at ARMA (Agency for Restructuring and Modernisation of Agriculture) since 2004. Contact email: joanna.czapska@yandex.com. 


\section{Keywords}

Ombudsman; Constitutional Tribunal; tax law; taxpayers' rights; legal entities

\section{JEL Classification: K38, K34, K40}

\section{Introduction}

The ascription of protected, normative rights seems to be possible with no doubts to entities that are not physical persons particularly in some areas. Che catalog of taxpayer rights of a certain kind could be singled out. However, a scope of these regulations remains controversial and is to be restricted mainly to the area of the economic law. There is a strict association of taxpayer rights and human rights in a law doctrine in Poland. Most of all, this topic-focused literature refers to taxpayers rights who are not physical persons and defined as legal entities. Law act regulations that are aimed to protect e.g. justified taxpayers rights are -at first sight- not adjusted to meet legislative needs of corporations. Particularly roles of Polish Ombudsman and Constitutional Tribunal are concerned in the field of constitutional appeal. The practice of mentioned organs found a different pathway and a number of cases with legal entities is still growing.

\section{Catalog of Taxpayers as Legal Entities}

Rights of taxpaying legal entities and scope of their protection are regulated to a much lesser extent than rights of other taxpayers. Besides constitutional regulations, which protect both groups of taxpayers (physical and legal entities), their rights are ensured also by acts. In Polish practice, rules of this sort are unfortunately scattered in the text of act titled in Polish Ordynacja Podatkowa (Ordinance Act of 27 August 1997) which plays a function of tax codification. ${ }^{4}$ Referral to sentences of constitutional courts has a great significance in this matter, too.

A catalogue of rights granted to legal entities can be divided into fundamental rights which correspond to economical rights acquired by physical persons (they cannot be defined broadly in case of either general rights or civil freedoms of economical sort - because it is impossible to assume that entity, that acquires legal identity, could have been granted any sort of congenital freedoms). In a set of fundamental taxpayer's legal regulations, the greatest significance can be ascribed to rights of proper tax legislation, property right, right to equal treatment, right to

4 Normative constitutional patterns are grounds for $93 \%$ of the control action in the field of tax law by Constitutional Tribunal. 
choice and right to running a business. Mentioned ones are protected by auxiliary rights (guarantee right) - like constitutional regulations: the right to judgment, right to legal proceedings in a court of second, superior instance, right to compensation due to illegal acts of treasury officers.

First, of mentioned laws, a right to proper tax legislation derives from a principle of legality of a democratic state, which is present in the majority of European constitutions. This principle of legality is founded within a catalog of postulates:

1) The postulate of clearness of tax regulations means that each taxpayer should have the possibility to recognize and understand tax law. Respect for this postulate is necessary for proper execution of the law. This can be achieved if only a tax regulation is formulated in clear, precise and easy-to-understand way. If these conditions are not met, actions of state authorities are going to negate the principle of tax stability and trust among a citizen, the law, and the state.

2) Principle of non-retroactivity - a principle of "lex retro non agit" forbids a start of validity for the disadvantageous modifications of law regulations before date of a publication of such a change (Ombudsman of Citizens' Rights: RPO-489470-VI/04/AB; Constitutional Tribunal: P.2/99; Constitutional Tribunal: U.1/86; Constitutional Tribunal: K.1/88; Constitutional Tribunal: K.6/91; Constitutional Tribunal: K.15/95; Constitutional Tribunal: K.15/91). Unfortunately, this rule has been constantly violated at the beginning of system transformation in Poland. For instance Act on income tax of legal entities enacted on 15 February 1992 came into force and was obligatory in recurrent mode from 1 February 1992. An act issued on 26 July 1991 about personal income tax (PIT) contained a part of regulations that were obligatory from 1 July 1991. Moreover, an act on 12 January 1991 about local taxes was binding from 1st January 1991. The Constitutional Tribunal announced that a recurrent mode of the validity of tax law regulations is acceptable and necessary if modifications are justified by the need of introduction of the proper interpretation of existing regulations, whose appliance is hindered by erroneous misunderstandings (Constitutional Tribunal: K.15/95).

3) The postulate of adequate length of vacatio legis. It is essentially important to give to addressees a time to read, understand and prepare to apply novel obligatory regulations of the act. It is indeed outrageous and dramatically confusing to enact acts that oblige from the date of publication. It is a constitutional demand to introduce an adequately long vacatio legis, depending on the complexity of law regulations (Constitutional Tribunal: K.2/94). This period should last at least 14 days according to Constitutional Tribunal (Constitutional Tribunal: W.3/90). Otherwise, citizens will suffer 
from exposition to an abuse of legislative authority. For a plenty of times, the Constitutional Tribunal underlined, that exact law novelties require the period of vacatio legis longer than 14 days. For example tax acts should be provided with at least one month long vacatio legis (Constitutional Tribunal: K.28/95). The Polish Ombudsman postulated that essential changes of annual tax should be announced at least half a year before the date of their entry into force. It is highly reprehensible that novel regulations of Tax Ordination came into force after a month and a half. On the other side, essential public business should be considered each time in perspective of the adequacy of vacatio legis. In the opinion of the Constitutional Tribunal, such an essential public business should be taken into account, for example in case of estimation of legislator's actions that are aimed at tax fraud and abuse (Constitutional Tribunal: K.2/94). According to Polish court, it can exceptionally justify limitation or even giving up the idea of introduction of any period of vacatio legis (Constitutional Tribunal: K.9/92). This essential public business can be characterized very broadly by the Constitutional Tribunal as it even can play a role in case of ensuring of execution of state budget incomes (Woltanowski, 2012: 51).

4) The postulate of avoidance of law modifications during vacatio legis comes from the fact that potential addressees of norm expect that an act in an original shape is going to be binding in a period defined in an act without any later surprising changes during vacatio legis. The legislative route of an act is so extensive, that it covers enactment inadequate mode by parliament, signed by the President of Polish State and in the end publishing in the Act Diary (pl. Dziennik Ustaw). A practice of act modifications during vacatio legis is confusing and causes doubts about the reliability of a legally established order and decreases a respect to legislative authority (Constitutional Tribunal: K.12/03). The Constitutional Tribunal is not consequent and underlines that the period of vacatio legis can be used for correction of errors, discovered after enacting of an act and verification of internal discrepancies. Moreover, vactatio legis can give some time to eliminate solutions evoking conflicts of regulations in the system of law or to prevent negative effects of the introduction of enacted but still not binding regulations (Constitutional Tribunal: K.12/03). According to the Constitutional Tribunal, these effects can particularly occur in the area of public finances. Furthermore, it could be supposed, that the Tribunal can justify similar changes in case of taxes with an argument that boundaries of the reliability of law were defined by the principle of proportionality. Reliability of law was always verified in perspectives of other constitutional values e.g. budgetary balance and state of public finances (Constitutional Tribunal: K.12/03) 
5) Prohibition of modification of tax law during the fiscal year results from two groups of premises. Less important technical premises refer to difficulties of a technical nature due to annuality of taxes. In order to change any element of income tax legislator would have to divide a fiscal year into parts or as it took place in 1993 a lawmaker would have to break a ban of the recurrent mode of law obligation. Arguments of substantial nature are more important than technical ones. One of them states citizens should have an assured right to take care of their interests according to tax duties before the start of fiscal year. Moreover, a constitutional jurisdiction often signalizes that state control is particularly strict in the establishment of tax (Constitutional Tribunal: K.13/93).

6) Right for undisturbed usage of one's property is protected by the state on the ground of both legislation and administration of the law. Tax burdens should differ proportionally and reasonably according to the wealth of taxpayers' groups. Sometimes, the property right is limited on the constitutional level by legislator by means of tax execution duty. In this case, property right and tax duty should be compromised in perspective of the extent of protection of a taxpayer's property. In addition, Polish constitutional court points at the principle of legality of a democratic state as a source of limitations and - originating from it - principles of justice and the common good. It is indispensable to preserve these constitutional values and respecting them together with the requirement of proportionality (Constitutional Tribunal: K.9/95). The essence of this law should not be violated by acceptable limitations deriving from the act (Constitution of Polish Republic, Art. 64/3).

7) Right for equal treatment was mostly expressed in the 32nd article of Polish Constitution. ${ }^{5}$ This article states that "all citizens are equal to the law ..." The present edition of this article (legislator used "all" and "nobody" terms) extends this law over not only physical but also legal entities who are represented not only by Polish citizens. Following detailed indications are the consequence of this article:

- Entities which this article refers to, are equal to the law;

- Entities have a right to equal treatment by public authorities;

- Entities may not be discriminated in any way in public, social and commercial life.

With no doubt, one statement of constitutional tribunal has still been very actual since 1988 and it says that "constitutional principle of equality to the law means that all legal entities (addressees of legal norms) that are characterized by a certain, relevant feature to the same extent, ought to be treated equally, according to the 
same measures with both discriminating a favoring differences." (Constitutional Tribunal: U.7/87) Both considering division of goods the same and in case of distribution of duties, it necessary to apply to differentiate category to make just and fair division among equal entities but separately in each category. Criterions, that determine initial categorization, are most of All: economic effectiveness of taxpayer and social aspects of taxation (Mastalski, 2016: 52). These criterions seem to be meet requirements that are issued by Constitutional Tribunal for exceptions from equal treatment of similar entities (Constitutional Tribunal: K.8/97):

- Criterions of differentiation should be of such a relevant nature, that they should be directly associated with purpose and content of legal regulations (these regulations contain a controlled norm). The criterions are to achieve this purpose and to execute the content of the regulations. Thus introduced differential ought to be rationally justified and they must not be established according to optionally chosen criterion (Constitutional Tribunal: K.3/94).

- A suitable proportion should be preserved with the importance of following interests:

- an interest, that is served by differentiation of legal events of addresses of the controlled norm;

- interests, which are to be violated in course of unequal treatment of similar entities (Constitutional Tribunal: K.8/97).

- Criterions, which determine differentiation of legal affairs of the entities ought to correspond with normative values of Polish Constitution Act that can ground dissimilar treatment of similar entities (Constitutional Tribunal: K.4/95).

The principle of equality is at high risk of being violated according to Constitutional Tribunal if only there is no rational explanation for existing differentiation in other words if this principle is of purely arbitrary nature. In the opinion of the Ombudsman, an example of such unjustified discrimination of some taxpayers was a differentiation in entitlement to decrease of proper excise tax $-\S 18 / 1$ rescript of Ministry of Finances dated 22 March 2002 in case of excise tax (Rescript in case of the excise tax, § 18/1). Precisely, disabling of decrease of excise tax for taxpayers, who started the sale of beer in a certain year, was opposite to with article 32nd in the light of article 84th of the Constitution of Republic of Poland (Ombudsman of Citizens' Rights: RPO-540136-VI/06). Unfortunately, concerning appliance of principle of equality as a constitutional pattern, Constitutional Tribunal expressed opinion of broadly extended freedom of legislator (Constitutional Tribunal: K.12/95) in the area of shaping tax duties (limits are mainly determined by rules of proper 
legislation and a requirement for tax not become a tool for confiscation of property (Constitutional Tribunal: K.8/97)).

8) A right to choice and run of a certain economic activity is sometimes limited by imposing of too high tax duties. It should be underlined that it is permissible to interfere in this law on the ground of constitution of the law e.g. by imposing an excise tax on certain products. However, execution of the law should be autonomic to the high extent in relation to economic and political aims of the state. In my point of view limitation and elimination of disadvantageous objects of economic activity could be regarded as proper and justified if only they are harmful to the environment, public health or if they break other constitutional values. This aim should be accomplished with the system of concessions, permissions or secondary limitations and tax duties (excise tax, differentiation of tax rate on the scale of income taxes). Elimination of economic activity ought not to take place with the use of inland revenues which would function as the machinery of repression. ${ }^{6}$

\section{Protection of Taxpayers' Rights who are not Physical Entities by the Ombudsman}

The scope of protection, assured by the Ombudsman, is varied in legal systems of different states, which support this institution. Initiators of this protection could be different in various states:

- The entity that initiates the control of the Ombudsman can be everybody and every institution (as in Poland, Slovenia, Estonia, and Hungary);

- The control of the Ombudsman can be evoked by entities which are listed in constitutional regulations (Albany - physical persons, personal groups, and non-government organizations);

- Only physical persons can initiate the Ombudsman's control in Bulgaria and Romania;

- In some countries (Cyprus and Malta) it is not precisely determined, which entities may appeal for control of the Ombudsman.

The Constitution of Polish Republic (art. 80) predicts that everybody can appeal to the Ombudsman not only Polish citizen but also foreigner or stateless person on

6 In 2010 to eliminate the distribution of psychoactive substances, Polish offices of treasury control launched a few massive controls in so-called smart shops. The largest one was conducted from 1st to 3rd September 2010 and it covered 849 shops (of total 1800 such all functioning ones). In result, 446 of these shops were subjected to control actions. It seems that authorities should not engage in special tormenting actions with help of Treasury Office and offices of tax control. Instead, authorities should rather execute the restricting law that would limit a distribution of psychoactive substances with Police forces and services in command of Ministry of Health. 
the territory of Poland under the jurisdiction of Polish law. Article $9^{\text {th }}$ of Act dated on 15th July 1987 on the Ombudsman defines that the control of the Ombudsman occurs:

- in the result of the application of citizens;

- in the result of the application of an organization of citizens;

- in the result of the application of bodies of self-government;

- in the result of the application of the Ombudsman of Children's Rights;

- in the result of the own initiative of the Ombudsman.

A term "organizations of citizens" means both legal entities and units without legal personality, though it is lately indicated that the last ones rarely are regarded as subjects of rights and duties. This point of view - may be true on the ground of private law, but it does not work on the ground of financial law.

In spite of the fact, that according to the act, control of the Ombudsman is launched due to the application of organization of citizens, foundations and limited companies turn out to claim for such a kind of protection. Foundations and companies are classified as legal entities, which are characterized by the domination of wealth and property aspect over nature of corporation (Świątkiewicz, 2001: 56).

Housing associations and communities or election committees are examples of entities without legal identity, which are covered by the protection of the Ombudsman. On the other side, it is controversial if protection of the Ombudsman may be accessed by such communities as:

- national minorities (whose rights to preserve their identity is protected on the ground of article 35th of the Constitution);

- local communities (who are granted a right to self-government in article 16th of the Constitution);

- churches and confessional associations (that a privileged with a right of autonomy in Art. 25 of the Constitution).

The Ombudsman's control may be also evoked by organs of self-government, councils of professions, cooperative societies, and councils of economic selfgovernment. The applications, that are directed by such entities, play a great role in the control of constitution and to the lesser extent also in the execution of the tax law.

There is no legally defined requirement of the personal application by the entity, whose rights and freedoms were violated. Application recipient organs and institutions are important sources for collection of information about a violation of rights of taxpayers e.g. Social Ombudsman of Entrepreneurs. Ombudsman of 
Entrepreneurs appeals to proper authorities with the request for the explanation of raised problems, issues a proposal for the start of legal administrative proceeding, participates in the legal proceeding as one side of a party, files complaint to administrative court or postulates modification of law regulations.

There is a debate on the establishment of a separate position of Ombudsman of taxpayer's rights in Poland for last few years. Lately, it has become even more sound in perspective of a project of the act for the appointment of such an organ for 5-years trial period. The project was enthusiastically welcomed by the largest organizations of business representatives. Such an Ombudsman's prerogatives and position in the legal system would be far different from US model of National Taxpayer Advocate. The Polish design of this function is rather a sort of doubling a model of Polish Ombudsman of Citizens' Rights with restriction to the protection of taxpayers' rights. Such an Ombudsman of Taxpayer's Rights (pl. Rzecznik Praw Podatnika, in short, RPP) would be elected by parliament for 5-year cadence being independent of other state authorities and would be supervised only by the lower chamber of Polish Parliament.

These would be entitlements of Ombudsman of Taxpayer's Rights:

- appealing to a certain organ, which violated taxpayers' rights or appealing to its supervising organ;

- evoking a start of a legal administrative proceeding and filing a complaint to administrative court, and participation in these proceedings with rights of the prosecutor;

- filing a complaint to Court of Cassation after legally valid sentence;

- appealing to Ministry of Finances to issue a general interpretation of standard guidelines in given events of tax law reality;

- appealing to Supreme Administrative Court to pass an explaining resolution for legal regulations in order to get rid of any doubts in practice of execution of these regulations and to avoid divergence in official interpretation of this regulations;

- appealing to proper organs with proposals of legislative initiative or issuing or modification of other legal acts in the field of taxpayer's rights;

- informing the Ombudsman of Citizens' Rights about the legitimacy of the appeal of this organ to Constitutional Tribunal.

An initial analysis of activities and results of studies in the Ombudsman's office and organizations of employers give ground for thesis, that a new organ doubles the only function of the Ombudsman of Citizens' Rights (in short RPO). There is also highly probable that such a new organ would easily turn from being the 
ombudsman of All the taxpayers to become the ombudsman of employer's rights. The mechanism of such an appropriation of a qualified ombudsman would probably look similar as in case of RPO. Most likely organizations of employers are going to provide Ombudsman of Taxpayer's Rights a significant part of applications and claims and their applications are going to be more professionally prepared than the others formulated by individual taxpayers. Employers would easily complete such applications with expert's reports and legal opinions on the demand of the Ombudsman of Taxpayer's Rights. If the state is not going to assure enough financial support for proper functioning of the Ombudsman of Taxpayer's Rights in the current era of the crisis of public finances, the Ombudsman's choice of considered cases would be restricted by mentioned financial background. Nevertheless, current experiences indicate that a new organ would be an essential and important part of the protection of institutional taxpayers launching economic activity.

\section{Protection of Taxpayers' Rights who are not Defined as Physical Persons with the Use of Constitutional Complaint}

An analysis of Art. 78 of the Constitution should be a starting point at the approach to the scope of the constitutional complaint. According to this article, "everybody can file a constitutional complaint if his or her constitutional freedoms were violated". It resembles little Austrian regulations, where legislator have not defined precisely circle of entitled subjects to lodge this complaint. ${ }^{7}$ A constitutional term "everybody" should be strictly defined in this area. The constitutional legislator does not use this objective term in a uniform meaning. There are a few application of the same term:

- usage of the term "everybody" as a synonymous for physical person e.g. in article 41 of the Constitution that refers to personal inviolability, in Art. 41 of the Constitution that founds rules of penal liability, in Art. 53 constituting liberty of conscience and religion;

- In broader aspect - "everybody" means also other legal entities than physical persons e.g. in Art. 45 of Constitution that formulated a right to the court proceeding, in Art. 63rd of Constitution - a right to petition and complaint; in Art. 80 giving legal ground to lodge a complaint to the Ombudsman. All these actions are basically defined as petitions. They are characterized by features of actio popularis and they serve as the realization of citizens' right can be filed by the legal entity that is characterized by legal interest or simply citizen. In Spain, this scope is extended to include additionally prosecutor and ombudsman (in form of so-called public complaint). 
to shape actions of public authorities and controlling them in order to protect interests of individuals, groups, and society.

In our opinion, entitled subjects, that file a constitutional complaint, should include physical persons, trade unions, organizations of employers, associations, political parties. Arguments of proposal interpretation, and court protection seem to support this point of view. The constitutional complaint ought to eliminate constitutionconflicting act and protect constitution guaranteed regulations, which refer not only to human beings but also to legal entities, that can use this legal instrument. Article 79 of the Constitution is remarkably placed in the chapter of Constitution titled "Sources of protection of liberties and rights" that also contain rights to reward, to the prosecution of interpretation or legal decisions and to appeal to the Ombudsman. In the establishment of mentioned entitlements, a term "everybody" covers also entities different from physical persons. Thus, it could be assumed that intention of the legislator was to include also such mentioned entities to a class of subjects that are competent to file a constitutional complaint. A right to the legal proceeding is granted also different entities from physical persons. Similarly to the constitutional complaint, a right to the legal proceeding is a kind of procedural guarantee of constitutional laws. In addition, a right to file a constitutional complaint could be acknowledged as a special form of right to the legal proceeding (that is further qualified according to kind of protection and mode of the proceeding). The term "everybody" should mean the same in both of mentioned regulations.

There is a little number of entities not defined as physical persons that file a constitutional file, probably because constitutional liberties and rights refer mainly to human and citizen. The Constitutional Tribunal states that "subjects that are entitled to file the constitutional complaint are - first of all - physical persons. Legal persons may file a constitutional complaint if only they protest against the violation of their rights or liberties. The scope of constitutional complaint is therefore limited by a range of certain constitutional liberties and rights" (Constitutional Tribunal: Ts.148/00). In light of my study of constitutional complaints, I cannot confirm that there is the low rate of constitutional complaints lodged by entities different from physical persons as suggested by reports in Polish literature. Particularly from 1996 to 2013 there was the relatively low rate of constitutional complaints issued by other entities than physical persons. The rate of sentences issued by Constitutional Tribunal in the field of tax law reached the level of $43 \%$ for legal entities. This paradoxically high rate for legal entities could be explained by the specificity of tax law. In generally liberties and tax rights, or economic freedoms refer both to physical persons and to legal entities. In addition, the number of constitutional complaints of physical persons' authorship is radically reduced by in preliminary procedure of formal quality control of filed complaints (approximately much over $90 \%$ of such complaints). There is a really striking disproportion of preliminarily 
rejected complaints of physical person Authorship in comparison to complaints filed by remaining entities - for last decade they have comprised $75 \%$ of all rejected complaints.

\section{Conclusions}

There is no need in the establishment of a quite new and distinct office named the Ombudsman of Taxpayers' rights because such an institution would only double some functions of the Ombudsman of citizens' rights. Instead, district representatives of the Ombudsman's office should be developed and specialized. Moreover, a greater financial support should be allocated for the current activity and the cooperation of the office with external experts and advisors. Thus, protective service of the Ombudsman would be accessible also for indigent taxpayers.

The right to appeal to Ombudsman should be guaranteed for taxpayers that are not physical persons. However, in practice, the Ombudsman should accept complaints that are filed by weaker participants of the economic cycle. A greater professionalism should be aimed at constitutional complaints - a current status of rejection of erroneous constitutional complaints is confusing, especially if complaints with errors are produced by professional representatives.

\section{References}

Mastalski, R.: Prawo podatkowe (Tax law), Warszawa: C.H. Beck, 2016.

Świątkiewicz, J.: Rzecznik Praw Obywatelskich w polskim systemie prawnym (Ombudsman of Citizens' Rights in Polish legal system), Warszawa: Prawo i Praktyka Gospodarcza, 2001.

Woltanowski, P.: Zasady prawidłowej legislacji podatkowej, a ochrona interesu Skarbu Państwa w orzecznictwie Trybunału Konstytucyjnego (The principle of proper tax legislation and protection of the interest of the State Treasury in the jurisprudence of the Constitutional Court), in: Etel, L., Tyniewicki, M. (eds.): Księga jubileuszowa profesora Eugeniusza Ruśkowskiego (Anniversary book of Professor Eugeniusz Ruśkowski), Bialystok: Temida 2, 2012.

PL: Constitution of the Republic of Poland of 2 April 1997, as amended.

PL: Ordinance Act of 27 August 1997, as amended.

PL: Constitutional Tribunal: K.12/03.

PL: Constitutional Tribunal: Ts.148/00.

PL: Constitutional Tribunal: P.2/99.

PL: Constitutional Tribunal: K.8/97. 
PL: Constitutional Tribunal: K.8/97.

PL: Constitutional Tribunal: K.12/95.

PL: Constitutional Tribunal: K.15/95.

PL: Constitutional Tribunal: K.9/95.

PL: Constitutional Tribunal: K.28/95.

PL: Constitutional Tribunal: K.2/94.

PL: Constitutional Tribunal: K.3/94.

PL: Constitutional Tribunal: K.13/93.

PL: Constitutional Tribunal: K.9/92.

PL: Constitutional Tribunal: K.6/91.

PL: Constitutional Tribunal: K.15/91.

PL: Constitutional Tribunal: W.3/90.

PL: Constitutional Tribunal: K.1/88.

PL: Constitutional Tribunal: U.7/87.

PL: Constitutional Tribunal: U.1/86.

PL: Ombudsman of Citizens' Rights: RPO-489470-VI/04/AB.

PL: Ombudsman of Citizens' Rights: RPO-540136-VI/06. 